\title{
An Importin- $\beta$-like Protein from Nicotiana benthamiana Interacts with the RNA Silencing Suppressor P1b of the Cucumber Vein Yellowing Virus, Modulating Its Activity
}

\author{
Beatriz García, Leonor Bedoya, Juan Antonio García (D) and Bernardo Rodamilans *(D)
}

check for updates

Citation: García, B.; Bedoya, L.; García, J.A.; Rodamilans, B. An Importin- $\beta$-like Protein from Nicotiana benthamiana Interacts with the RNA Silencing Suppressor P1b of the Cucumber Vein Yellowing Virus, Modulating Its Activity. Viruses 2021, 13, 2406. https://doi.org/10.3390/ v13122406

Academic Editor: Maria Amelia Sánchez Pina

Received: 11 November 2021 Accepted: 29 November 2021 Published: 30 November 2021

Publisher's Note: MDPI stays neutral with regard to jurisdictional claims in published maps and institutional affiliations.

Copyright: (c) 2021 by the authors. Licensee MDPI, Basel, Switzerland. This article is an open access article distributed under the terms and conditions of the Creative Commons Attribution (CC BY) license (https:/ / creativecommons.org/licenses/by/ $4.0 /)$.
Centro Nacional de Biotecnología CNB, Consejo Superior de Investigaciones Científicas CSIC, 28049 Madrid, Spain; bggarcia@cnb.csic.es (B.G.); leonorbedoya@gmail.com (L.B.); jagarcia@cnb.csic.es (J.A.G.)

* Correspondence: brodamilans@cnb.csic.es

\begin{abstract}
During a plant viral infection, host-pathogen interactions are critical for successful replication and propagation of the virus through the plant. RNA silencing suppressors (RSSs) are key players of this interplay, and they often interact with different host proteins, developing multiple functions. In the Potyviridae family, viruses produce two main RSSs, HCPro and type B P1 proteins. We focused our efforts on the less known P1b of cucumber vein yellowing virus (CVYV), a type B P1 protein, to try to identify possible factors that could play a relevant role during viral infection. We used a chimeric expression system based on plum pox virus (PPV) encoding a tagged CVYV P1b in place of the canonical HCPro. We used that tag to purify P1b in Nicotiana-benthamiana-infected plants and identified by mass spectrometry an importin- $\beta$-like protein similar to importin 7 of Arabidopsis thaliana. We further confirmed the interaction by bimolecular fluorescence complementation assays and defined its nuclear localization in the cell. Further analyses showed a possible role of this $N$. benthamiana homolog of Importin 7 as a modulator of the RNA silencing suppression activity of P1b.
\end{abstract}

Keywords: Potyviridae; RNA silencing suppression; importin $\beta$; P1b; cucumber vein yellowing virus

\section{Introduction}

Plant viral infections are based on a myriad of protein interactions that represent the fight between the host, trying to stop pathogen replication and spread, and the virus, searching to exploit plant resources for its own benefit [1-3]. Some interactions are pro-viral, and some are pro-plant, and in some cases, the same protein could be essential for plant defense and, at the same time, be important during the viral life cycle [4,5]. This complexity reflects the elaborate interplay developed during the plant-virus co-evolution process [6].

One of the main assets viruses use against plant defenses, specifically RNA silencing, are RNA silencing suppressors (RSSs), and practically all plant viruses express at least one protein with this specific function [7-9]. Potyviridae, the largest family of plant RNA viruses, is no exception to this. Most of its members are monopartite, presenting a single-stranded positive sense RNA of $10 \mathrm{~Kb}$ [10-12], whose main ORF encodes a large polyprotein that is processed by viral endopeptidases $[13,14]$. A secondary ORF, produced after polymerase slippage [15-17], encodes an extra product essential for viral movement [18,19]. Apart from the secondary role as RSS of the VPg of some potyviruses $[20,21]$ and the exceptionality of the enlarged P1 proteins of sweet potato infecting potyviruses $[8,17,22,23]$, there are two proteins in the family that function as RSS: HCPro and P1, specifically type B P1. HCPro is a well-known multifunctional protease that helps in aphid transmission and viral particle formation, acting as an RSS at least in potyviruses and rymoviruses [24]. It is a protein extensively studied, and the list of identified interacting host factors continuously grows [4,24-26]. Type B P1 proteins are less characterized. They take on the role of RSSs in cases in which the virus encodes no HCPro, such as the ipomovirus known as cassava 
brown streak virus [27], or when HCPro does not have RSS activity, as is the case of tritimoviruses [28] and poaceviruses [29].

Cucumber vein yellowing virus (CVYV) is an ipomovirus that infects cucurbitaceae species, such as cucumber, melon, and watermelon [30]. It does not encode HCPro and presents at the beginning of the polyprotein two P1 endopeptidases of type $\mathrm{A}$ and type $\mathrm{B}$ (named P1a and P1b, respectively) [31]. P1a is involved in host range definition [32,33], while P1b is the main viral RSS [34]. This protease bears the $\mathrm{LX}_{2} \mathrm{AX}_{6}+\mathrm{Zn}$ finger motif characteristic of type B P1 proteins [22,35] and functions as an RSS by sequestering small RNAs, resembling HCPro [36] and probably other type B P1 proteases in the family [37-39]. P1b host partners are basically unknown, and only recently the host factor HYD1 was described as a possible interacting protein playing a defensive role during viral infection [40].

Finding plant interactors of this key viral protein would increase our knowledge about potyviral infections and could provide new tools to develop novel antiviral strategies. Thus, we focused our efforts on identifying new interactors of CVYV P1b in Nicotiana benthamiana. We used a chimeric virus based on plum pox virus (PPV), in which PPV HCPro was replaced by CVYV P1b. To facilitate P1b purification during viral infection, we included an N-terminal tag, similar to the one used for the identification of host partners in the case of HCPro of potato virus A (PVA) [41]. We managed to identify as the main candidate an importin- $\beta$-like protein, homolog of Importin 7 of Arabidopsis thaliana, with multiple roles inside the cell: nuclear transport [42], ABA signaling and response [43], and modulation of the miRNA pathway [44]. Our characterization of the interaction between $\mathrm{P} 1 \mathrm{~b}$ and the $\mathrm{N}$. benthamiana homolog of Importin 7 and its effect in the plant identified a new possible role of this host protein as a regulator of the action of viral RSSs.

\section{Materials and Methods}

\subsection{Plasmids}

Plasmids were generated using standard molecular cloning procedures. PCR reactions were performed with Phusion High-Fidelity DNA Polymerase (New England BioLabs, Ipswich, MA, USA). Primers were synthesized by Merck (Darmstadt, Germany), and sequencing of all products was carried out by Macrogen (Seoul, Korea). The primers are listed in Table S2. Restriction enzymes and T4-DNA ligase were purchased from Thermo Fisher Scientific (Waltham, MA, USA) and New England BioLabs (Ipswich, MA, USA). pPPV has been previously described in [45], and PPPV-SIIIP1b was obtained by modifying the reported $\mathrm{pPPV}_{\triangle \mathrm{HC}}$ plasmid [45]. The SIIIP1b fragment was obtained by PCR amplification using primers $2712 / 2711$ and using as a template a previously generated PICPPV-SIIIP1b plasmid (data not shown). The resulting product was ligated to $\mathrm{pPPV}_{\triangle \mathrm{HC}}$ digested with SwaI, and this enzyme was included in the reaction mix to reduce background colonies [46]. pENTRY-Imp7 cDNA was obtained by reverse transcription with Superscript III (Thermo Fisher Scientific, Waltham, MA, USA) from total RNA purified from $N$. benthamiana leaves with Plant Total RNA purification Mini Kit (Favorgen, Ping-Tung, Taiwan). Due to the large size of NbImp7, amplification from $N$. benthamiana cDNA was performed in two fragments using primers 3328/3276 and 3275/3247. Fragments were cloned into pENTRY plasmid (Invitrogen, Waltham, MA, USA) digested with BstxI and EcoRV using the Gibson assembly kit (New England BioLabs, Ipswich, MA, USA). All the clones that we obtained presented a STOP codon mutation in the middle of the sequence, suggesting this protein was deleterious for the bacteria. To overcome this problem, one of the plasmids with the STOP codon ( $\mathrm{pENTRY-Imp} 7^{\mathrm{STOP}}$ ) was used as a template for the amplification of two PCR products using primers $2940 / 3351$ and 3352/3353. Fragments were joined together by overlapping PCR using primers 2940/3353, and the product was digested with SphI and SacI and cloned into pUC19 plasmid digested with the same enzymes (pUC-Imp7Frag). This new plasmid was used as a template for two PCR reactions using primers 705/3367 and 3368/706. Another PCR was performed using as a template PPPV with the primers 3366/3369. All three PCR products were joined together by overlapping PCR using primers $705 / 706$, and the PCR product was digested with SphI and SacI and cloned into the original pENTRY- 
Imp $7^{\text {STOP }}$ digested with the same enzymes. The plasmids pBIFP2-Imp7, pGWB702 $\Omega$-Imp7, pGWB702 $\Omega$-SIIIP1b, and pBIFP3-P1 were constructed using the GATEWAY system. pBIFP2Imp7 and pGWB702 $\Omega$-Imp7 were obtained by LR recombination of pENTRY-Imp7 with pBIFP2 [47] and pGWB702 $\Omega$ [48], respectively. pDONR207-SIIIP1b was obtained by BP recombination of pDONR207 (Invitrogen, Waltham, MA, USA) with an SIIIP1b fragment amplified by PCR using as a template pPPV-SIIIP1b and primers 3558/890. LR recombination of this plasmid with pGWB702 $\Omega$ [48] yielded pGWB702 $\Omega$-SIIIP1b. pDONR207-P1 was obtained by BP recombination of pDONR207 with a P1 fragment amplified by PCR using as a template $\mathrm{PPPV}$ and primers $3818 / 3099$. LR recombination of this plasmid with pBIFP3 [47] yielded pBIFP3-P1. pBIFP3-P1b, pBIFP3-P1b ${ }_{C 89 A}$ and pBIFP3-P1b RK68,69AA have been previously reported [35], as has mRFP-NLS [49]. pBIN61:p19 and pGFP were kindly provided by Prof. David Baulcombe (University of Cambridge, Cambridge, UK).

\subsection{Agroinfiltration}

Plants of $N$. benthamiana wild type and of the GFP transgenic line 16C [50] were grown in a greenhouse maintained in a $16 \mathrm{~h}$ light $/ 8 \mathrm{~h}$ dark cycle and a temperature range of $19-23^{\circ} \mathrm{C}$. Plants were infiltrated as described [34], using cultures of the Agrobacterium tumefaciens strain C58C1-313 [51], carrying the indicated binary plasmid at an $\mathrm{OD}_{600}$ of 0.5 in all cases except for the bacteria carrying pGWB702 $\Omega-\operatorname{Imp} 7$ or the corresponding empty plasmids that were used at an $\mathrm{OD}_{600}$ of 0.75 .

\subsection{SIIIP1b Purification}

Purification was performed following the reported protocol [52]. Briefly, tissue from 6 plants of $N$. benthamiana inoculated with either pPPV-SIIIP1b or pPPV, collected at $12 \mathrm{dpa}$, was smashed under liquid nitrogen and resuspended in a binding buffer $(25 \mathrm{mM}$ Tris- $\mathrm{HCl}$, pH 8.0; $550 \mathrm{mM} \mathrm{NaCl}, 5 \mathrm{mM} \mathrm{NaF}, 0.5 \mathrm{mM}$ EDTA, $10 \%$ glycerol ( $v / v), 0.1 \mathrm{mM}$ PMSF). Samples were centrifuged, and the supernatant was collected. After adding avidin to a final concentration of $100 \mu \mathrm{g} / \mathrm{mL}$, the sample was mixed with Strep-Tactin resin (IBA, Göttingen, Germany), previously cross-linked with BS3 (Thermo Fisher Scientific, Waltham, MA, USA), and left incubating for $30 \mathrm{~min}$ at $4{ }^{\circ} \mathrm{C}$ in a spin column (Corning, New York, NY, USA). Three cycles of centrifugation and wash ( $25 \mathrm{mM}$ Tris-HCl, $\mathrm{pH} 8.0,500 \mathrm{mM} \mathrm{NaCl}$, $5 \mathrm{mM} \mathrm{NaF}, 0.4 \mathrm{mM}$ EDTA, 0.2\% Igepal CA-360 $(v / v), 5 \%$ glycerol $(v / v), 0.1 \mathrm{mM}$ PMSF) were performed before elution of the bound proteins with the corresponding buffer $(25 \mathrm{mM}$ Tris- $\mathrm{HCl}$, $\mathrm{pH} 8.0$, SDS 1\% $(w / v))$.

\subsection{Mass Spectrometry Analyses}

pPPV- and pPPV-SIIIP1b-eluted samples were applied to a conventional SDS-PAGE gel and stopped as soon as the front entered the resolving gel. Unseparated protein bands were excised and processed automatically in a Proteineer DP (Bruker Daltonics, Bremen, Germany). Digestion protocol was reported [53]. Half of each digested sample was subjected to 1D-nano LC ESI-MSMS analysis using a nano liquid chromatography system (Eksigent Technologies nanoLC Ultra 1D plus, SCIEX, Foster City, CA, USA) coupled to a high-speed Triple TOF 5600 mass spectrometer (SCIEX, Foster City, CA, USA) with a Nanospray III source. The analytical column used was the silica-based reversed phase Acquity UPLC ${ }^{\circledR}$ M-Class Peptide BEH C18 Column (Waters, Milford, MA, USA). The trap column was a C18 Acclaim PepMapTM 100 (Thermo Fisher Scientific, Waltham, MA, USA) switched online with the analytical column. Peptides were separated using a $40 \mathrm{~min}$ gradient ranging from $(98 \% \mathrm{~A}-2 \% \mathrm{~B})$ to $(10 \% \mathrm{~A}-90 \% \mathrm{~B})(\mathrm{A}: 2 \%$ acetonitrile, $0.1 \%$ formic acid; B: $100 \%$ acetonitrile, $0.1 \%$ formic acid). Data were acquired with TripleTOF 5600 System (SCIEX, Foster City, CA, USA), using an ionspray voltage floating (ISVF) set at $2300 \mathrm{~V}$, curtain gas (CUR) set to 35, an interface heater temperature (IHT) of 150, ion source gas 1 (GS1) set at 25 , and declustering potential (DP) set at $100 \mathrm{~V}$. All data were obtained using information-dependent acquisition (IDA) mode with Analyst TF 1.7 software (SCIEX, Foster City, CA, USA). Mass spectrometry data obtained were processed using PeakView 
v2.2 Software (SCIEX, Foster City, CA, USA) and searched using Mascot Server v2.5.0 (Matrix Science, London, UK) against $N$. benthamiana protein database from Solgenomics (last update: 10 July 2015, 57.153 sequences), together with viral sequences and commonly occurring contaminants.

\subsection{Image Analyses}

BiFC images were acquired at 6 dpa by confocal laser scanning microscopy using a Leica TCS SP8 system with laser line WLL2 and HyD detectors. YFP detection was done using a laser line at $514 \mathrm{~nm}(16.7 \%)$ and $\mathrm{HyD}$ at 520 and $558 \mathrm{~nm}$. RFP detection was done using a laser line at $560 \mathrm{~nm}(33.5 \%)$ and $\mathrm{HyD}$ at 575 and $628 \mathrm{~nm}$. For GFP fluorescence images taken with a Leica MZFLIII epifluorescence microscope, we used excitation and barrier filters at $470 / 40$ and 525/50 nm. Images were acquired with an Olympus DP70 digital camera at the indicated times.

\subsection{Fluorescence Analysis}

GFP fluorescence intensity quantification was carried out placing individual $5.0 \mathrm{~mm}$ diameter leaf discs collected at $5 \mathrm{dpa}$ in a black 96-well plate (Nunc) filled with $100 \mu \mathrm{L}$ water/well and acquiring the signal in a monochromator-based plate reader (Infinite M200, Tecan Group, Männedorf, Switzerland) [54]. Two discs per plant were collected. Statistical analysis was performed by Student's $t$-test $(p<0.01)$.

\subsection{RT-PCR and -qPCR}

Total RNA was extracted from N. benthamiana plants using Plant Total RNA Purification Mini Kit from Favorgen (Ping-Tung, Taiwan) following manufacturer's instructions. cDNA was prepared using Superscript III (Thermo Fisher Scientific, Waltham, MA, USA). SIIIP1b amplification for checking the presence of the N-terminal tag was performed using primers 90/1444. qPCR reactions were prepared with technical triplicates using HOT FIREPol EvaGreen qPCR Mix Plus (Solis BioDyne, Tartu, Estonia) in 96-well optical plates and run in a 7500HT Fast Real-Time PCR system (Applied Biosystems, Waltham, MA, USA). Primer pairs for NbImp7 (3242/3243) were selected using Primer3 [55]. Primers for GFP amplification (3227/3228) were reported [8], as were primers for the reference gene Fbox (2808/2809) [56]. Relative quantification was performed as described [57].

\section{Results}

\subsection{P1b Interacts with and Importin- $\beta$-Like Protein of Nicotiana benthamiana during Viral Infection}

Using a Strep tag II in tandem (SIII) at the amino terminus of an RSS gave interesting results in the case of HCPro of PVA, allowing the identification of various host protein interactors relevant for the viral life cycle [41]. Employing a similar approach, we engineered a PPV construct in which HCPro was replaced by CVYV P1b with an SIII N-terminal tag (pPPV-SIIIP1b) to facilitate purification of the protein during viral infection (Figure 1a). A similar construct expressing P1b without a tag was previously tested, showing that the chimeric virus was functional $[58,59]$. We inoculated by agroinfiltration six plants with pPPV-SIIIP1b and six plants with pPPV, which expresses the native HCPro, as a negative control. Both viruses express GFP as an engineered reporter of viral infection. Upper non-inoculated leaves of infected plants showing strong GFP fluorescence signal were collected at 12 days post agroinfiltration (dpa). The presence of the SIII tag and the intact P1b sequence in the genome of the viral progeny was confirmed by RT-PCR before SIIIP1b purification (data not shown). Following the protocol described [52], we purified SIIIP1b from the pPPV-SIIIP1b-inoculated tissue and performed in parallel the same purification process using the tissue inoculated with pPPV (Figure 1b). The final eluted samples were analyzed by mass spectrometry, producing a list of peptides for each sample matching the proteins of $N$. benthamiana. Seventy-eight host proteins were identified in the pPPV sample, and forty-eight were retrieved in the case of pPPV-SIIIP1b (Table S1). Most of the proteins 
were identified by the presence of a single matching peptide. When at least two peptides were included as a requisite for identification, the list was reduced to 23 proteins for the pPPV sample and 10 proteins for pPPV-SIIIP1b. From those, six proteins were common to both samples and there were only four proteins unique in the case of the SIIIP1b containing sample (Figure 1c). Two of these proteins represented two alleles of the same gene, an importin- $\beta$-like protein similar to Importin 7 of $A$. thaliana (ran binding protein 7 , also termed SAD2). This protein will be hereinafter referred to as NbImp7. The other two proteins were an activase of $\mathrm{RuBisCO}$ and a heat shock protein. The experiment was repeated, and the results obtained were similar, with the identification of NbImp7 and the other two proteins as the primary targets of the pPPV-SIIIP1b-infected sample (Table S1).

(a)

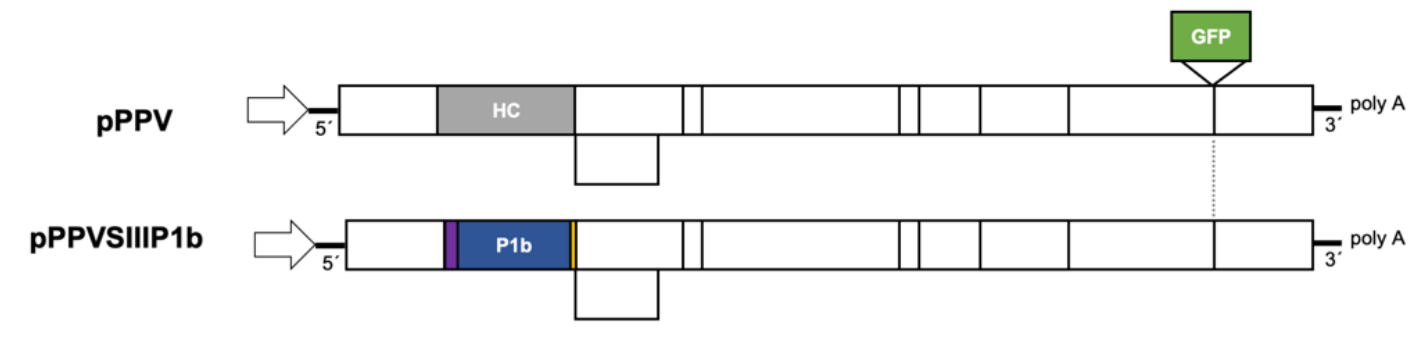

(b)

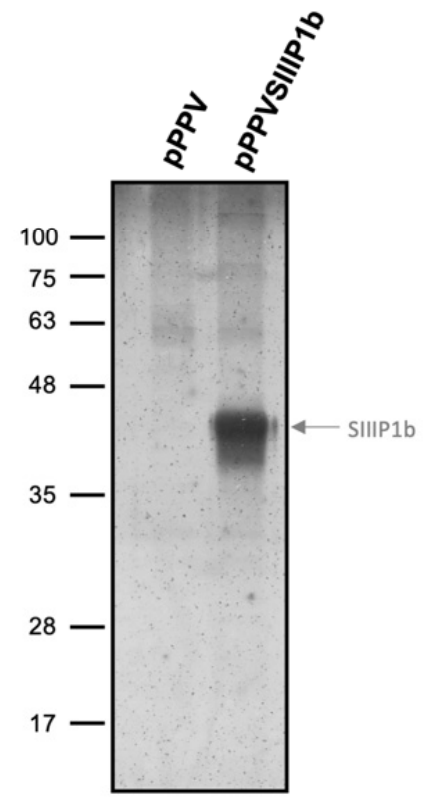

(c)

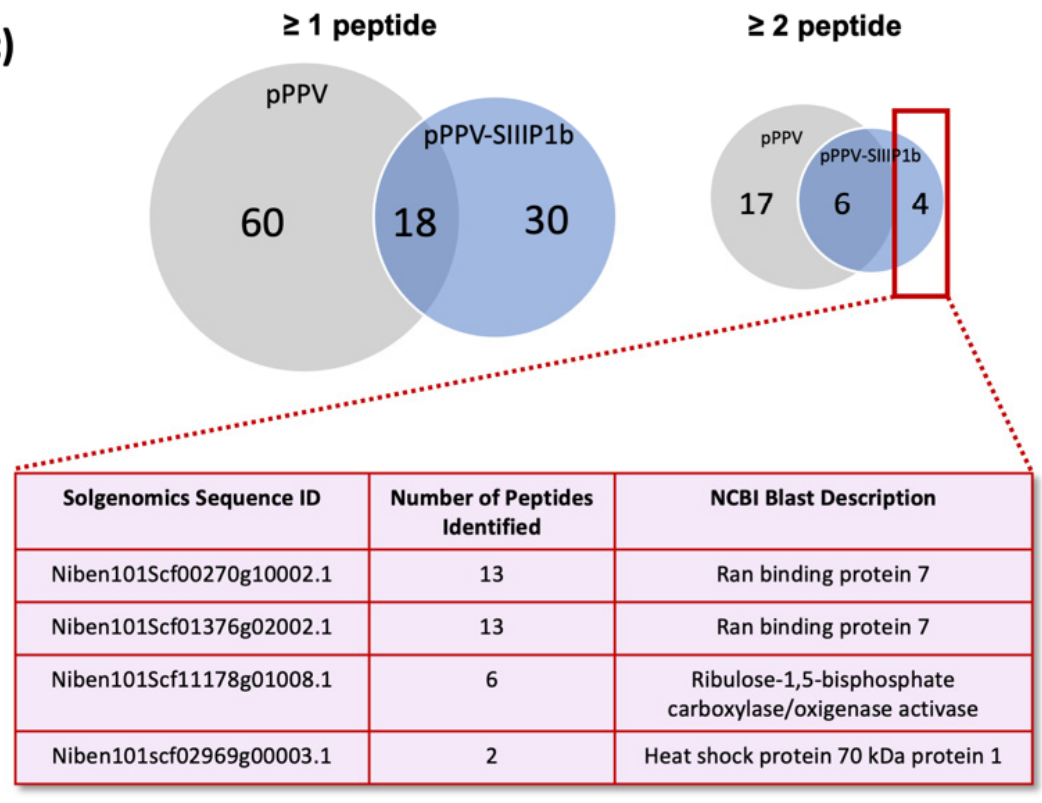

Figure 1. Purification and mass spectrometry analysis of SIIIP1b from PPV- and PPV-SIIIP1b-infected tissue. (a) Schematic representation of the two viral constructs employed in this assay. Both encode the GFP sequence between the NIb and CP regions. The purple rectangle represents the SIII tag, and the yellow rectangle represents the NIa cleavage site. (b) Silver staining of the SDS-PAGE analysis of PPV and PPV-SIIIP1b samples after elution from the Streptactin resin. The molecular weight is on the left; the arrow on the right indicates the estimated size of the SIIIP1b product. (c) Venn diagrams of the mass spectrometry results obtained from the analyzed samples using one or more peptide or two or more peptide identification. The four proteins shown in the table below correspond to the targets found exclusively in the pPPV-SIIIP1b sample.

3.2. Interaction between NbImp7 and P1b Occurs in the Nucleus of the Cell, Depends on a Correct Folding of P1b, but Is Independent of Its Ability to Bind siRNA

To confirm an already identified interaction between a viral protein and a host protein and discard false positives due to technical issues, it is important to test the interaction by an alternative method [60]. We decided to use bimolecular fluorescence complementation assays (BiFC) for this, since it allowed us to evaluate the interaction, testing at the same time its intracellular location and providing a good opportunity to check different P1b mutants. $\mathrm{NbImp7}$ was cloned by Gybson assembly after amplification of the gene by RT-PCR from 
$N$. benthamiana tissue. The protein appeared to be toxic for bacteria, and final cloning was not possible until an intron was introduced in the middle of the NbImp7 coding sequence. NbImp7 was cloned into the plasmid pBIFP2 to express the C-terminal part of YFP at its $\mathrm{N}$-terminus (P-Imp7), and the rest of the viral proteins tested were cloned into the plasmid pBIFP3 to express the $\mathrm{N}$-terminal part of YFP also at the N-terminus (YF-protein of interest). BiFC experiments were carried out twice using two independent clones of each construct and agroinfiltrating two leaves from two different plants. To avoid RNA silencing, a plasmid expressing tombusviral RSS P19 was included in all cases. Samples were analyzed under confocal microscopy at $6 \mathrm{dpa}$. Obtained results were consistent between constructs and between experiments. Initial $\mathrm{BiFC}$ assays showed a green fluorescence signal when YF-P1b was co-infiltrated with P-Imp7 while showing no fluorescence when YF-P1b was co-expressed with an empty plasmid $\mathrm{P}-\varnothing$ (Figure $2 \mathrm{a}$ ). $\mathrm{P} 1 \mathrm{~b}_{\mathrm{C} 89 \mathrm{~A}}$ mutant, a protein that displays an aberrant structural conformation [35], was used as a negative control for the NbImp7 interaction, and, as anticipated, it showed no fluorescence complementation with P-Imp7. These results confirmed the previously observed interaction between P1b and NbImp7 in N. benthamiana. However, P1 $b_{\mathrm{RK} 68,69 \mathrm{AA}}$, a double mutant that preserves the standard P1b structure but lacks siRNA binding ability [35], showed strong fluorescence, indicating that siRNA binding is not relevant for the NbImp7-P1b interaction.

(a)

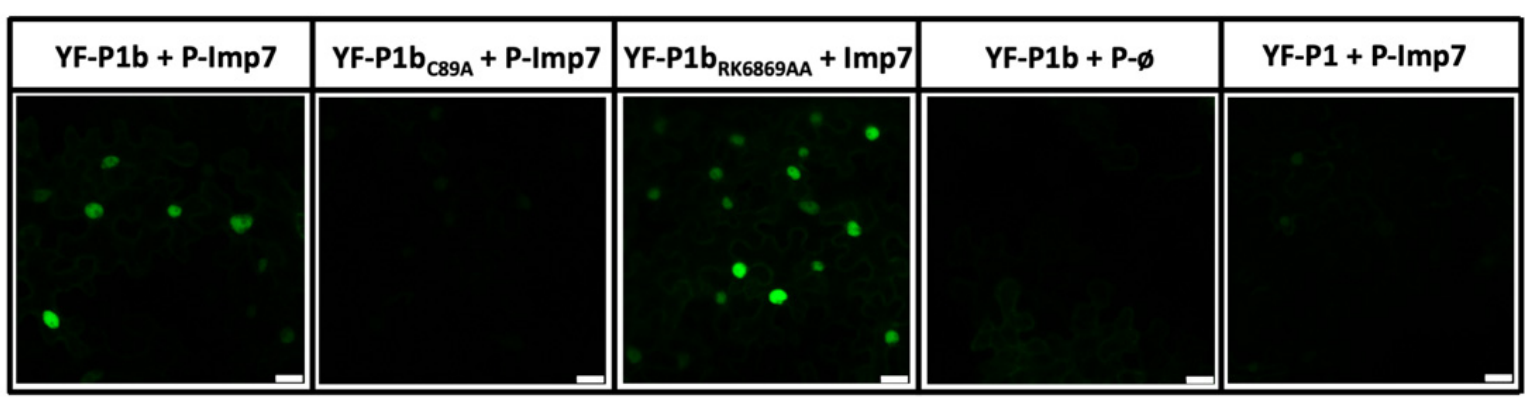

(b)

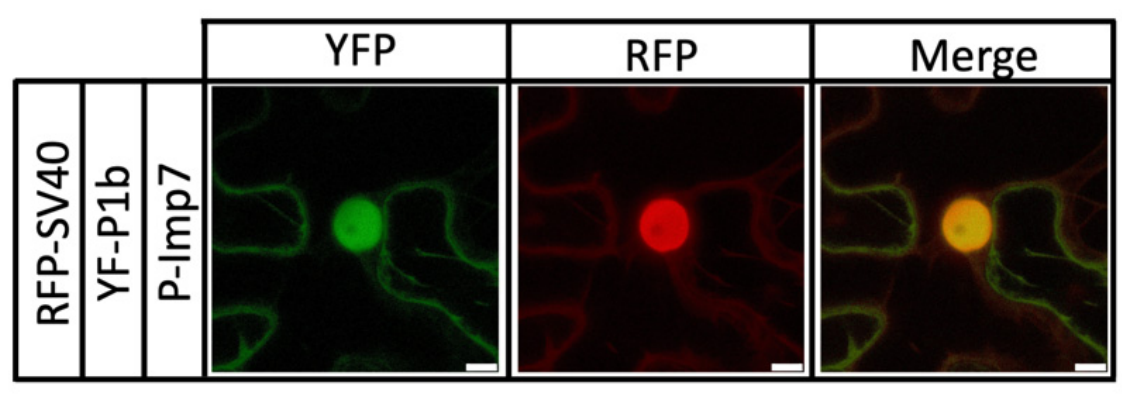

Figure 2. BiFC analysis to test the interaction of $\mathrm{P} 1 \mathrm{~b}$ with $\mathrm{NbImp} 7$ and its cellular localization. Images were taken with a confocal microscope at $6 \mathrm{dpa}$. (a) P1b and two P1b mutants, as well as P1, were expressed together with P-Imp7 and were tested for YFP fluorescence complementation. An empty plasmid, P-ø, was used as the negative control. The white bar indicates $25 \mu \mathrm{M}$. (b) YFP, RFP, and merge fluorescence of the same sample agroinfiltrated with the indicated constructs. The white bar indicates $10 \mu \mathrm{M}$.

Due to the described relationship between the NbImp7 protein of $A$. thaliana (SAD2) and two potyviral P1 proteins [61,62], we also performed BiFC analysis using PPV P1 fused to YF (YF-P1). The result showed that, at least under these experimental conditions, there is no interaction between these two proteins (Figure 2a). Focusing on the cellular location of the complementation, it appeared that the interaction between NbImp7 and P1b was taking place in the nucleus of the cell. To verify this, a plasmid carrying a nuclear protein from SV40 marked with an RFP tag at the N-terminus (mRFP-NLS) [49] was co-agroinfiltrated with YF-P1b and P-Imp7. The merged results confirmed the initial observation, showing that the YFP fluorescence and the RFP nuclear fluorescence were coincidental (Figure 2b). 


\subsection{NbImp7 Is Overexpressed in the Plant after P1b Expression and during a Viral Infection}

It is not uncommon for host proteins involved in a viral infection to suffer some rearrangements on their expression either by up- or by downregulation, during the pathogen attack [63]. To understand a little better the behavior of NbImp7 after potyviral infection and more specifically during P1b overexpression, we tested the mRNA levels of $\mathrm{NbImp7}$ of the corresponding tissue by quantitative PCR (qPCR). We agroinfiltrated four N. benthamiana plants (two clones per construct and two plants per clone) with either an empty plasmid, a plasmid expressing SIIIP1b, or the viral plasmids PPPV and PPPV-SIIIP1b. Inoculated leaves were collected at $6 \mathrm{dpa}$ for analysis, while upper non-inoculated leaves were collected at $10 \mathrm{dpa}$, after verifying the presence of GFP fluorescence in plants agroinfiltrated with the viral constructs. Analysis of the qPCR data (Figure 3) revealed strong upregulation of NbImp7 mRNA levels upon SIIIP1b overexpression in the inoculated leaves (left panel) compared to the control, while preserving similar NbImp7 mRNA levels in the upper non-inoculated leaves (right panel). However, a significant increase compared to the control, although not as pronounced as in the case of SIIIP1b overexpression, was also observed in the case of PPPV and pPPV-SIIIP1b infection, in inoculated and upper systemic leaves (left panel and right panel, respectively).
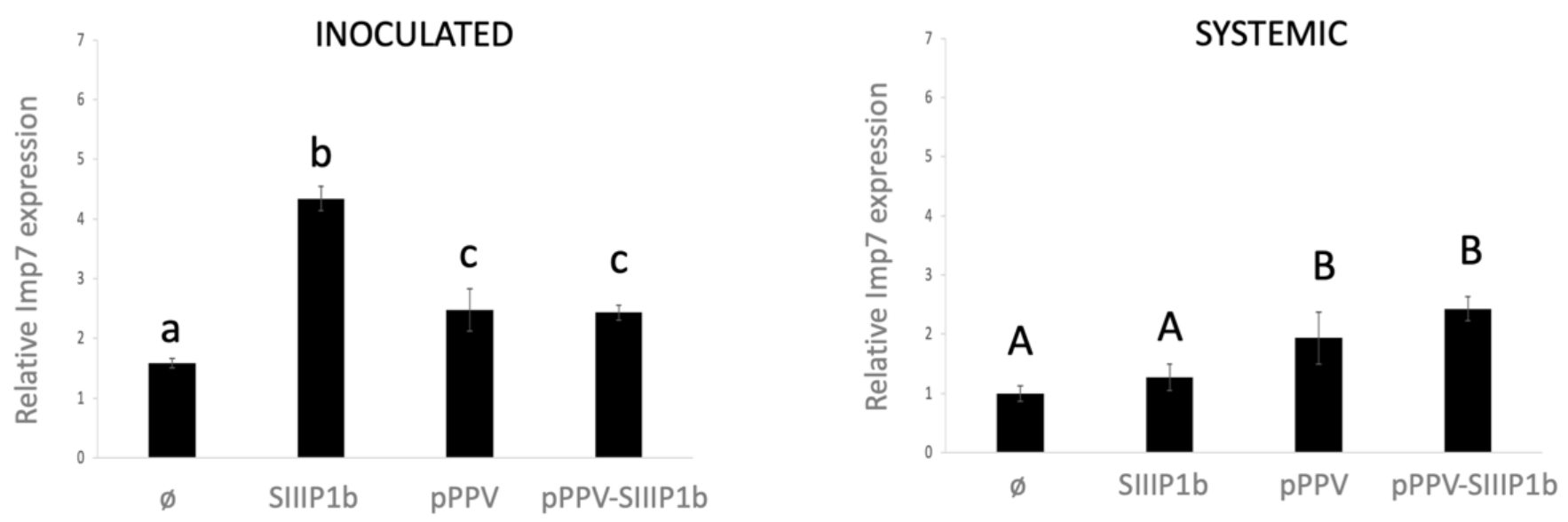

Figure 3. Evaluation of NbImp7 mRNA levels after P1b transient expression or after viral infection. RT-qPCR experiments to assess the mRNA expression of NbImp7, taking as reference the value of this mRNA in upper leaves of mock inoculated plants. Samples of inoculated leaves (left) were collected at $6 \mathrm{dpa}$; samples of systemically infected leaves (right) were collected at $12 \mathrm{dpa}$. Analysis of variance $(n=4 ; p<0.05)$ (one-way ANOVA), followed by Tukey's post hoc test, was performed; and letters indicate the different groups.

\subsection{Expression of NbImp7 Interferes with P1b Ability to Suppress RNA Silencing}

Considering that $\mathrm{NbImp7} \mathrm{mRNA} \mathrm{in} N$. benthamiana plants was upregulated upon $\mathrm{P} 1 \mathrm{~b}$ expression (Figure 3), it was reasonable to assume that an artificial overexpression of NbImp7 could have an effect, positive or negative, on this RSS, providing clues as to what could be the role of this protein during viral infection. Thus, a transient co-expression system was employed and to better assess the RNA silencing capacity of SIIIP1b, 16C line $N$. benthamiana plants expressing GFP were used. Four plants per condition (two plants per clone) were agroinfiltrated in each case. Empty vectors $\mathrm{pGWB702 \Omega}$ and SIIIP1b were tested, with and without $\mathrm{NbImp} 7$ co-expression. Plants were co-agroinfiltrated with a plasmid encoding GFP (pGFP), and they were monitored at $3 \mathrm{dpa}$ and $5 \mathrm{dpa}$ (Figure 4a), collecting samples at $5 \mathrm{dpa}$. GFP fluorescence was measured by taking discs of the corresponding leaves, and the same discs were used for RNA extraction and qPCR analysis (Figure $4 b$ ). In the case of SIIIP1b samples, GFP fluorescence showed a clear downregulation when NbImp7 was co-expressed with the suppressor instead of the empty plasmid (left panel). This result was coincidental with the qPCR analysis (right panel), in which a significant reduction in the mRNA levels of GFP could be observed when NbImp7 was included in 
(a)

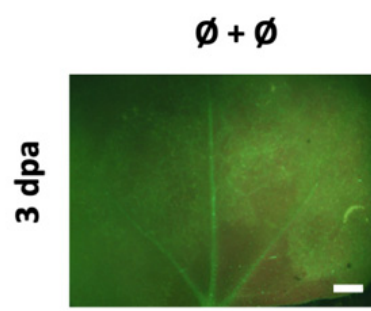

the mix. When pGWB702 $\Omega$ was tested instead of SIIIP1b, the effect of NbImp7 in GFP fluorescence was the opposite. However, the qPCR results did not show variation in GFP mRNA levels whether NbImp7 was co-agroinfiltrated or not.
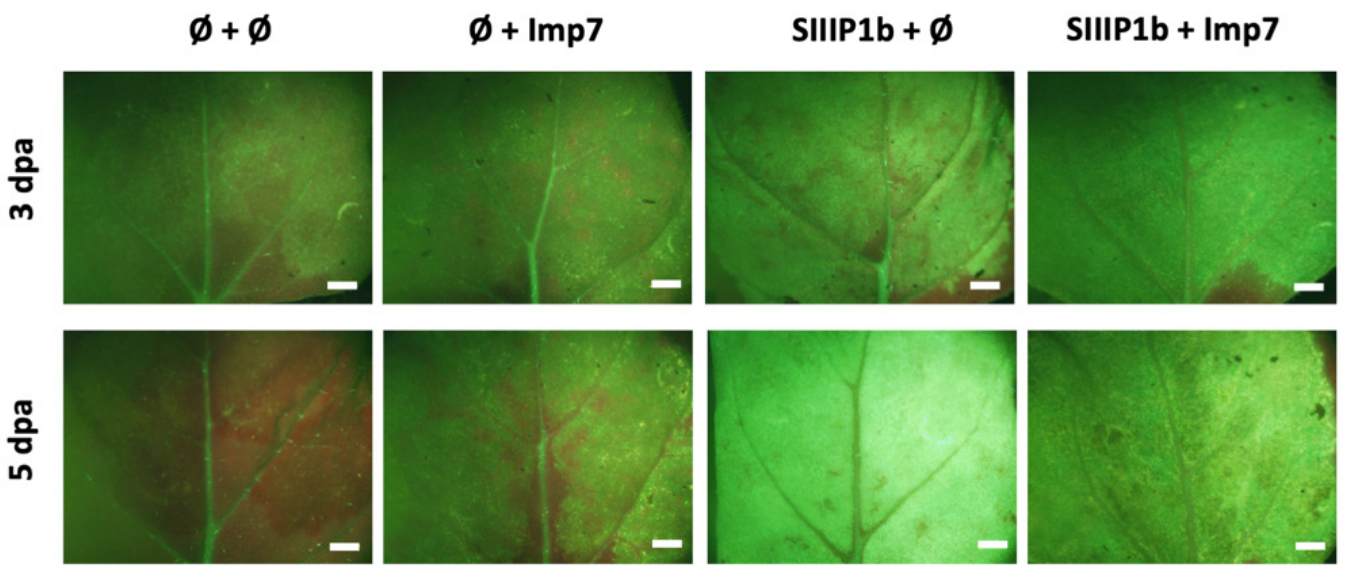

(b)
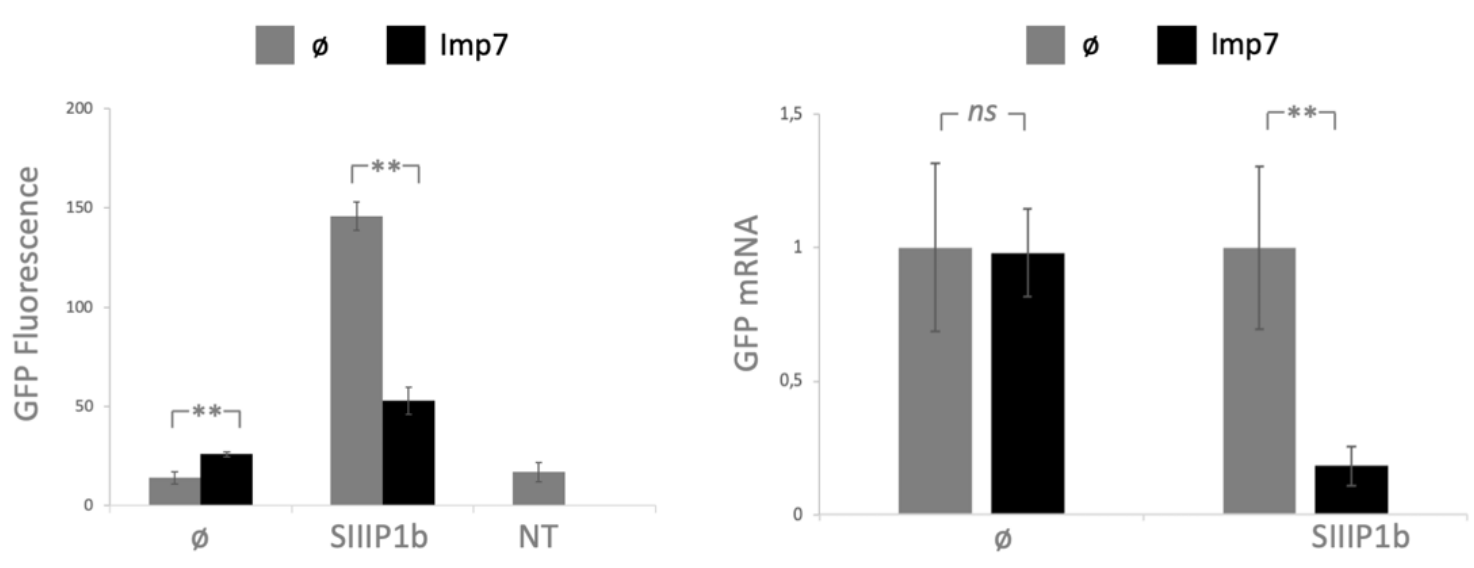

Figure 4. Effect of NbImp7 overexpression on SIIIP1b RNA silencing suppression activity. (a) Microscope images from 16C line N. benthamiana plants agroinfiltrated with the couple of indicated plasmids and pGFP, taken at $3 \mathrm{dpa}$ and $5 \mathrm{dpa}$. The white bar indicates $2 \mathrm{~mm}$. (b) Quantitative analyses of GFP expression of agroinfiltrated leaves collected at $5 \mathrm{dpa}$. To the left, GFP fluorescence relative to the signal obtained from wild type N. benthamiana plants; NT, non-treated 16C line N. benthamiana. To the right, RT-qPCR analysis of GFP mRNA expression relative to control plants agroinfiltrated with pGFP and only an empty plasmid. Statistical analysis by $t$-test was performed $\left(n s=\right.$ not significant; ${ }^{* *}=p<0.01$ ).

\section{Discussion}

Type B P1 proteins are one of the two main RSSs employed by viruses of the Potyviridae family to counteract the RNA silencing defense mechanism of the plant. Their mode of action as an RSS is well described, binding siRNAs [35,36] and large RNAs [37] or directly interfering with AGO1 protein [64]. Nonetheless, knowledge about the host factors they interact with during a viral infection is scarce $[40,64]$.

We decided to study type B P1 protein CVYV P1b and find possible interactors in N. benthamiana plants. A chimeric virus expressing this RSS instead of HCPro was used, and an N-terminal SIII tag was employed to help in the identification process. Analysis of the P1b-associated samples by mass spectrometry revealed the presence of an interesting candidate, clearly identified in two independent experiments: an importin- $\beta$-like protein, homolog to Importin 7 protein of $A$. thaliana (Figure 1). Interaction was further confirmed by BiFC assays, which also showed that correct folding, but not the siRNA binding capacity of P1b, was relevant for the interaction (Figure 2a). The nuclear localization of the protein 
interplay (Figure 2b) was confirmed using a nuclear marker protein tagged with RFP. Transport to the nucleus of viral RSSs is not unusual [65-67] and in some cases is mandatory for their activity as suppressors [68]. However, the mode of action of P1b, sequestering siRNAs, suggests that the cytoplasm should be its primary location. It is possible that $\mathrm{P} 1 \mathrm{~b}$ is developing an unknown function in the nucleus, but it is also possible that the protein in that compartment is actually trapped in an undesirable location. Considering that Importin 7 of $A$. thaliana was described to help in the transport to the nucleus of transcription factor MYB4 [42], it is reasonable to speculate that NbImp7 could be doing the same with P1b in N. benthamiana plants.

It is interesting to note that type A P1 proteins are described to travel to the nucleus during viral infection [69] and appear to have Importin-7-like proteins as possible interactors [61,62]. We tested by BiFC the possible relationship between type A P1 of PPV and NbImp7, but the result was negative (Figure 2a). This was not strange considering the different viruses (PPV vs. PSbMV and TuMV) and the different experimental hosts (N. benthamiana vs. Pisum sativum and A. thaliana) used. Nonetheless, it seems clear that this importin is in a close relationship with P1 viral proteins, whether type A or type B, and this could suggest that the conserved protease domain was involved in the interaction.

The large upregulation of NbImp7 transcripts upon SIIIP1b expression reinforces the relationship of these two proteins and suggests that their interaction could be functional (Figure 3). The high expression of NbImp7 during pPPV-SIIIP1b infection goes along this line and could be related to the expression of the SIIIP1b RSS in the plant. Observing the same effect on NbImp7 expression during pPPV infection, which encodes no P1b, adds complexity to the picture. It is possible that PPV P1 is involved in this behavior, but the BiFC results (Figure 2a) suggest otherwise. Two other possibilities are considered: (i) the viral infection per se causes the upregulation of NbImp7 mRNA, and (ii) HCPro is playing the role of SIIIP1b and causes NbImp7 upregulation. The latter possibility would suggest that NbImp7 is able to interact also with the structurally unrelated HCPro. Although uncommon, a promiscuous behavior of this type has already been described for the endogenous RSS rgsCaM [70], which interacted with different kinds of viral RSSs, such as potyviral HCPro, cucumoviral $2 b$, and even with the Tat protein of human immunodeficiency virus. Further investigation is needed to elucidate this issue.

The transient expression experiments performed with SIIIP1b and NbImp7 (Figure 4) shed some light on the effect that this host protein overexpression could be having during viral infection. Interestingly, the expression of NbImp7 alone had a positive effect on GFP fluorescence, indicating an increase in protein accumulation. This increase could be due to an RNA silencing suppression activity of $\mathrm{NbImp7}$, given that a similar function was already described for its Arabidopsis homolog [44]. If this was the case, and considering that the difference in fluorescence was not accompanied by a difference in mRNA accumulation, NbImp7 would not be acting by suppressing mRNA degradation but by relieving silencing derived from translational repression [71,72]. However, the results obtained with SIIIP1b were solid, indicating a strong reduction both at the protein and at the mRNA levels. Overall, this last result suggests that NbImp7 might be hampering the role of SIIIP1b as an RSS either by hijacking the protein in the nuclear compartment, as previously suggested, or by other means, such as proteasome-mediated degradation, as was the case of rgsCaM [70], siRNA modulation/sequestration, etc. Thus, the interaction between SIIIP1b and NbImp7 could be involved in the plant antiviral defense mechanism. Nonetheless, considering some precedents $[73,74]$, we cannot discard the possibility that the virus was using this repression to modulate its own RNA silencing suppression activity, favoring viral infection.

Identifying new interactions between host factors and viral proteins is a difficult but necessary task, since it is this interplay that reveals the actual functions and mechanisms behind the viral infection. We identified a new interaction between an importin- $\beta$-like protein, NbImp7, and a type B P1 protein, P1b. Our data suggest this interaction is functional, affecting viral RSS behavior inside the cell. Understanding the role of this interplay will improve our knowledge about potyviral infections and could help define a 
new function of $\mathrm{NbImp7} \mathrm{in} \mathrm{the} \mathrm{defensive} \mathrm{system} \mathrm{of} \mathrm{the} \mathrm{plant,} \mathrm{as} \mathrm{well} \mathrm{as} \mathrm{reveal} \mathrm{unknown}$ functions of the potyviral RSSs in the nucleus of the cell. Future research will help verify the relevance of this interaction and its involvement during viral infection.

Supplementary Materials: The following are available online at https:/ / www.mdpi.com/article/ 10.3390/v13122406/s1, Table S1: Mass spectrometry analyses, Table S2: List of primers used in the study.

Author Contributions: B.R. and J.A.G. designed the study; L.B. conducted the initial experiment, while B.G. conducted the rest of the experimental work; B.R. prepared the original draft, and all authors review the manuscript. All authors have read and agreed to the published version of the manuscript.

Funding: This research was funded by Ministerio de Ciencia e Innovación, grant number PID2019109380RBI00/AEI/301 10.13039/501100011033.

Institutional Review Board Statement: Not applicable.

Informed Consent Statement: Not applicable.

Data Availability Statement: The data that support the findings of this study are available from the corresponding author upon reasonable request.

Acknowledgments: We are grateful to the Proteomics facility and the Advanced Light Microscopy Facility of CNB for their work and to David Baulcombe for providing GFP and p19 expression plasmids and the $16 \mathrm{C}$ line of $N$. benthamiana.

Conflicts of Interest: The authors declare no conflict of interest. The funders had no role in the design of the study; in the collection, analyses, or interpretation of data; in the writing of the manuscript; or in the decision to publish the results.

\section{References}

1. Garcia-Ruiz, H. Host factors against plant viruses. Mol. Plant Pathol. 2019, 20, 1588-1601. [CrossRef]

2. Rodamilans, B.; Valli, A.; García, J.A. Molecular Plant-Plum Pox Virus Interactions. Mol. Plant-Microbe Interact. 2020, 33, 6-17. [CrossRef]

3. Wang, A. Dissecting the molecular network of virus-plant interactions: The complex roles of host factors. Annu. Rev. Phytopathol. 2015, 53, 45-66. [CrossRef] [PubMed]

4. Pollari, M.; De, S.; Wang, A.; Mäkinen, K. The potyviral silencing suppressor HCPro recruits and employs host ARGONAUTE1 in pro-viral functions. PLoS Path. 2020, 16, e1008965. [CrossRef]

5. Jeon, E.J.; Tadamura, K.; Murakami, T.; Inaba, J.I.; Kim, B.M.; Sato, M.; Atsumi, G.; Kuchitsu, K.; Masuta, C.; Nakahara, K.S. Rgs-CaM Detects and Counteracts Viral RNA Silencing Suppressors in Plant Immune Priming. J. Virol. 2017, 91, e00761-17. [CrossRef] [PubMed]

6. McLeish, M.J.; Fraile, A.; García-Arenal, F. Evolution of plant-virus interactions: Host range and virus emergence. Curr. Opin. Virol. 2019, 34, 50-55. [CrossRef]

7. Csorba, T.; Kontra, L.; Burgyán, J. Viral silencing suppressors: Tools forged to fine-tune host-pathogen coexistence. Virology 2015, 479-480, 85-103. [CrossRef]

8. Mingot, A.; Valli, A.; Rodamilans, B.; San León, D.; Baulcombe, D.C.; García, J.A.; López-Moya, J.J. The P1N-PISPO transFrame Gene of Sweet Potato Feathery Mottle Potyvirus Is Produced during Virus Infection and Functions as an RNA Silencing Suppressor. J. Virol. 2016, 90, 3543-3557. [CrossRef]

9. Zhao, J.H.; Hua, C.L.; Fang, Y.Y.; Guo, H.S. The dual edge of RNA silencing suppressors in the virus-host interactions. Curr. Opin. Virol. 2016, 17, 39-44. [CrossRef] [PubMed]

10. Revers, F.; García, J.A. Molecular biology of potyviruses. Adv. Virus Res. 2015, 92, 101-199. [CrossRef]

11. Walker, P.J.; Siddell, S.G.; Lefkowitz, E.J.; Mushegian, A.R.; Adriaenssens, E.M.; Dempsey, D.M.; Dutilh, B.E.; Harrach, B.; Harrison, R.L.; Hendrickson, R.C.; et al. Changes to virus taxonomy and the Statutes ratified by the International Committee on Taxonomy of Viruses. Arch. Virol. 2020, 165, 2737-2748. [CrossRef]

12. Yang, X.; Li, Y.; Wang, A. Research Advances in Potyviruses: From the Laboratory Bench to the Field. Annu. Rev. Phytopathol. 2021, 59, 1-29. [CrossRef]

13. Mann, K.S.; Sanfacon, H. Expanding Repertoire of Plant Positive-Strand RNA Virus Proteases. Viruses 2019, 11, 66. [CrossRef]

14. Rodamilans, B.; Shan, H.; Pasin, F.; Garcia, J.A. Plant Viral Proteases: Beyond the Role of Peptide Cutters. Front. Plant Sci. 2018, 9, 666. [CrossRef]

15. Chung, B.Y.; Miller, W.A.; Atkins, J.F.; Firth, A.E. An overlapping essential gene in the Potyviridae. Proc. Natl. Acad. Sci. USA 2008, 105, 5897-5902. [CrossRef] 
16. Olspert, A.; Chung, B.Y.; Atkins, J.F.; Carr, J.P.; Firth, A.E. Transcriptional slippage in the positive-sense RNA virus family Potyviridae. EMBO Rep. 2015, 16, 995-1004. [CrossRef] [PubMed]

17. Rodamilans, B.; Valli, A.; Mingot, A.; San León, D.; Baulcombe, D.; López-Moya, J.J.; García, J.A. RNA polymerase slippage as a mechanism for the production of frameshift gene products in plant viruses of the Potyviridae family. J. Virol. 2015, 89, 6965-6967. [CrossRef]

18. Wei, T.; Zhang, C.; Hong, J.; Xiong, R.; Kasschau, K.D.; Zhou, X.; Carrington, J.C.; Wang, A. Formation of complexes at plasmodesmata for potyvirus intercellular movement is mediated by the viral protein P3N-PIPO. PLoS Path. 2010, 6, e1000962. [CrossRef] [PubMed]

19. Wen, R.H.; Hajimorad, M.R. Mutational analysis of the putative pipo of soybean mosaic virus suggests disruption of PIPO protein impedes movement. Virology 2010, 400, 1-7. [CrossRef]

20. Rajamäki, M.L.; Streng, J.; Valkonen, J.P. Silencing suppressor protein VPg of a potyvirus interacts with the plant silencing-related protein SGS3. Mol. Plant-Microbe Interact. 2014, 27, 1199-1210. [CrossRef] [PubMed]

21. Cheng, X.; Wang, A. The potyvirus silencing suppressor protein VPg mediates degradation of SGS3 via ubiquitination and autophagy pathways. J. Virol. 2017, 91, 16. [CrossRef] [PubMed]

22. Rodamilans, B.; Casillas, A.; García, J.A. P1 of Sweet Potato Feathery Mottle Virus Shows Strong Adaptation Capacity, Replacing P1-HCPro in a Chimeric Plum Pox Virus. J. Virol. 2021, 95, e0015021. [CrossRef]

23. Untiveros, M.; Olspert, A.; Artola, K.; Firth, A.E.; Kreuze, J.F.; Valkonen, J.P. A novel sweet potato potyvirus ORF is expressed via polymerase slippage and suppresses RNA silencing. Mol. Plant Pathol. 2016, 17, 1111-1123. [CrossRef]

24. Valli, A.A.; Gallo, A.; Rodamilans, B.; López-Moya, J.J.; García, J.A. The HCPro from the Potyviridae family: An enviable multitasking Helper Component that every virus would like to have. Mol. Plant Pathol. 2017, 19, 744-763. [CrossRef]

25. De, S.; Pollari, M.; Varjosalo, M.; Mäkinen, K. Association of host protein VARICOSE with HCPro within a multiprotein complex is crucial for RNA silencing suppression, translation, encapsidation and systemic spread of potato virus A infection. PLoS Path. 2020, 16, e1008956. [CrossRef]

26. Yang, T.; Qiu, L.; Huang, W.; Xu, Q.; Zou, J.; Peng, Q.; Lin, H.; Xi, D. Chilli veinal mottle virus HCPro interacts with catalase to facilitate virus infection in Nicotiana tabacum. J. Exp. Bot. 2020, 71, 5656-5668. [CrossRef]

27. Mbanzibwa, D.R.; Tian, Y.; Mukasa, S.B.; Valkonen, J.P. Cassava brown streak virus (Potyviridae) encodes a putative Maf/HAM1 pyrophosphatase implicated in reduction of mutations and a P1 proteinase that suppresses RNA silencing but contains no HC-Pro. J. Virol. 2009, 83, 6934-6940. [CrossRef]

28. Young, B.A.; Stenger, D.C.; Qu, F.; Morris, T.J.; Tatineni, S.; French, R. Tritimovirus P1 functions as a suppressor of RNA silencing and an enhancer of disease symptoms. Virus Res. 2012, 163, 672-677. [CrossRef] [PubMed]

29. Tatineni, S.; Qu, F.; Li, R.; Morris, T.J.; French, R. Triticum mosaic poacevirus enlists P1 rather than HC-Pro to suppress RNA silencing-mediated host defense. Virology 2012, 433, 104-115. [CrossRef] [PubMed]

30. Caciagli, P.; Janssen, D.; Louro, D.; Vaira, A.M.; Winter, S. Cucumber vein yellowing virus (Ipomovirus). EPPO Bull. 2007, 37, 554-559.

31. Valli, A.; López-Moya, J.J.; García, J.A. Recombination and gene duplication in the evolutionary diversification of P1 proteins in the family Potyviridae. J. Gen. Virol. 2007, 88, 1016-1028. [CrossRef]

32. Shan, H.; Pasin, F.; Tzanetakis, I.E.; Simón-Mateo, C.; García, J.A.; Rodamilans, B. Truncation of a P1 leader proteinase facilitates potyvirus replication in a non-permissive host. Mol. Plant Pathol. 2017, 19, 1504-1510. [CrossRef]

33. Shan, H.; Pasin, F.; Valli, A.; Castillo, C.; Rajulu, C.; Carbonell, A.; Simón-Mateo, C.; García, J.A.; Rodamilans, B. The Potyviridae P1a leader protease contributes to host range specificity. Virology 2015, 476, 264-270. [CrossRef]

34. Valli, A.; Martín-Hernández, A.M.; López-Moya, J.J.; García, J.A. RNA silencing suppression by a second copy of the P1 serine protease of Cucumber vein yellowing ipomovirus, a member of the family Potyviridae that lacks the cysteine protease HCPro. J. Virol. 2006, 80, 10055-10063. [CrossRef] [PubMed]

35. Valli, A.; Dujovny, G.; Garcia, J.A. Protease activity, self interaction, and small interfering RNA binding of the silencing suppressor p1b from cucumber vein yellowing ipomovirus. J. Virol. 2008, 82, 974-986. [CrossRef]

36. Valli, A.; Oliveros, J.C.; Molnar, A.; Baulcombe, D.; García, J.A. The specific binding to 21-nt double-stranded RNAs is crucial for the anti-silencing activity of Cucumber vein yellowing virus $\mathrm{P} 1 \mathrm{~b}$ and perturbs endogenous small RNA populations. RNA 2011, 17, 1148-1158. [CrossRef]

37. Gupta, A.K.; Tatineni, S. Wheat streak mosaic virus P1 binds to dsRNAs without size and sequence specificity and a GW Motif Is crucial for suppression of RNA silencing. Viruses 2019, 11, 472. [CrossRef] [PubMed]

38. Gupta, A.K.; Tatineni, S. RNA silencing suppression mechanisms of Triticum mosaic virus P1: dsRNA binding property and mapping functional motifs. Virus Res. 2019, 269, 197640. [CrossRef]

39. Chen, J.; Liang, S.; Sun, S.; Damaj, M.; Fu, H.; Gao, S. Diverse conserved domains and a positively selected site in the sugarcane streak mosaic virus P1 protein are essential for RNA silencing suppression and protein stability. Plant Pathol. 2020, 69, 1390-1400. [CrossRef]

40. Ochoa, J.; Valli, A.; Martín-Trillo, M.; Simón-Mateo, C.; García, J.A.; Rodamilans, B. Sterol isomerase HYDRA1 interacts with RNA silencing suppressor P1b and restricts potyviral infection. Plant Cell Environ. 2019, 42, 3015-3026. [CrossRef]

41. Ivanov, K.I.; Eskelin, K.; Basic, M.; De, S.; Lohmus, A.; Varjosalo, M.; Mäkinen, K. Molecular insights into the function of the viral RNA silencing suppressor HCPro. Plant J. 2016, 85, 30-45. [CrossRef] 
42. Zhao, J.; Zhang, W.; Zhao, Y.; Gong, X.; Guo, L.; Zhu, G.; Wang, X.; Gong, Z.; Schumaker, K.S.; Guo, Y. SAD2, an importin -like protein, is required for UV-B response in Arabidopsis by mediating MYB4 nuclear trafficking. Plant Cell 2007, 19, 3805-3818. [CrossRef]

43. Verslues, P.E.; Guo, Y.; Dong, C.H.; Ma, W.; Zhu, J.K. Mutation of SAD2, an importin beta-domain protein in Arabidopsis, alters abscisic acid sensitivity. Plant J. 2006, 47, 776-787. [CrossRef]

44. Wang, W.; Ye, R.; Xin, Y.; Fang, X.; Li, C.; Shi, H.; Zhou, X.; Qi, Y. An importin beta protein negatively regulates MicroRNA activity in Arabidopsis. Plant Cell 2011, 23, 3565-3576. [CrossRef] [PubMed]

45. Rodamilans, B.; Valli, A.; Mingot, A.; San Leon, D.; Lopez-Moya, J.J.; Garcia, J.A. An atypical RNA silencing suppression strategy provides a snapshot of the evolution of sweet potato-infecting potyviruses. Sci. Rep. 2018, 8, 15937. [CrossRef] [PubMed]

46. Ma, J.; Wang, Y.; Wang, Y. A simple, fast and efficient method for cloning blunt DNA fragments. Afr. J. Biotechnol. 2013, 12, 4094-4097.

47. Azimzadeh, J.; Nacry, P.; Christodoulidou, A.; Drevensek, S.; Camilleri, C.; Amiour, N.; Parcy, F.; Pastuglia, M.; Bouchez, D. Arabidopsis TONNEAU1 proteins are essential for preprophase band formation and interact with centrin. Plant Cell 2008, 20, 2146-2159. [CrossRef] [PubMed]

48. Tanaka, Y.; Nakamura, S.; Kawamukai, M.; Koizumi, N.; Nakagawa, T. Development of a series of gateway binary vectors possessing a tunicamycin resistance gene as a marker for the transformation of Arabidopsis thaliana. Biosci. Biotechnol. Biochem. 2011, 75, 804-807. [CrossRef]

49. Serra-Soriano, M.; Pallás, V.; Navarro, J.A. A model for transport of a viral membrane protein through the early secretory pathway: Minimal sequence and endoplasmic reticulum lateral mobility requirements. Plant J. 2014, 77, 863-879. [CrossRef]

50. Ruiz, M.T.; Voinnet, O.; Baulcombe, D.C. Initiation and maintenance of virus-induced gene silencing. Plant Cell 1998, 10, 937-946. [CrossRef]

51. Pasin, F.; Bedoya, L.C.; Bernabé-Orts, J.M.; Gallo, A.; Simón-Mateo, C.; Orzaez, D.; García, J.A. Multiple T-DNA delivery to plants using novel mini binary vectors with compatible replication origins. ACS Synth. Biol. 2017, 6, 1962-1968. [CrossRef] [PubMed]

52. Ivanov, K.I.; Basic, M.; Varjosalo, M.; Mäkinen, K. One-step purification of twin-strep-tagged proteins and their complexes on strep-tactin resin cross-linked with bis(sulfosuccinimidyl) suberate (BS3). J. Vis. Exp. 2014, 86, 51536. [CrossRef]

53. Shevchenko, A.; Wilm, M.; Vorm, O.; Mann, M. Mass spectrometric sequencing of proteins silver-stained polyacrylamide gels. Anal. Chem. 1996, 68, 850-858. [CrossRef]

54. Pasin, F.; Kulasekaran, S.; Natale, P.; Simón-Mateo, C.; García, J.A. Rapid fluorescent reporter quantification by leaf disc analysis and its application in plant-virus studies. Plant Methods 2014, 10, 22. [CrossRef] [PubMed]

55. Koressaar, T.; Lepamets, M.; Kaplinski, L.; Raime, K.; Andreson, R.; Remm, M. Primer3_masker: Integrating masking of template sequence with primer design software. Bioinformatics 2018, 34, 1937-1938. [CrossRef]

56. Liu, D.; Shi, L.; Han, C.; Yu, J.; Li, D.; Zhang, Y. Validation of reference genes for gene expression studies in virus-infected Nicotiana benthamiana using quantitative real-time PCR. PLoS ONE 2012, 7, e46451. [CrossRef] [PubMed]

57. Pfaffl, M.W. A new mathematical model for relative quantification in real-time RT-PCR. Nucleic Acids Res. 2001, 29, e45. [CrossRef]

58. Carbonell, A.; Dujovny, G.; García, J.A.; Valli, A. The Cucumber vein yellowing virus silencing suppressor P1b can functionally replace HCPro in Plum pox virus infection in a host-specific manner. Mol. Plant-Microbe Interact. 2012, 25, 151-164. [CrossRef]

59. Maliogka, V.I.; Calvo, M.; Carbonell, A.; García, J.A.; Valli, A. Heterologous RNA-silencing suppressors from both plant- and animal-infecting viruses support plum pox virus infection. J. Gen. Virol. 2012, 93, 1601-1611. [CrossRef]

60. Fukao, Y. Protein-protein interactions in plants. Plant Cell Physiol. 2012, 53, 617-625. [CrossRef]

61. Hu, S.F.; Wei, W.L.; Hong, S.F.; Fang, R.Y.; Wu, H.Y.; Lin, P.C.; Sanobar, N.; Wang, H.P.; Sulistio, M.; Wu, C.T.; et al. Investigation of the effects of P1 on HC-pro-mediated gene silencing suppression through genetics and omics approaches. Bot. Stud. 2020, 61, 22. [CrossRef]

62. Rohozková, J.; Sebela, M.; Nvrátil, M. P1 peptidase of Pea seed-borne mosaic virus contains non-canonical C2H2 zinc finger and may act in a truncated form. J. Plant Mol. Breed. 2014, 3, 1-7. [CrossRef]

63. Zanardo, L.G.; de Souza, G.B.; Alves, M.S. Trnascriptomics of plant-virus interactions: A review. Theor. Exp. Plant Physiol. 2019, 31, 103-125. [CrossRef]

64. Giner, A.; Lakatos, L.; García-Chapa, M.; López-Moya, J.J.; Burgyan, J. Viral protein inhibits RISC activity by argonaute binding through conserved WG/GW motifs. PLoS Path. 2010, 6, e1000996. [CrossRef] [PubMed]

65. Mayers, C.N.; Palukaitis, P.; Carr, J.P. Subcellular distribution analysis of the cucumber mosaic virus 2b protein. J. Gen. Virol. 2000, 81 Pt 1, 219-226. [CrossRef]

66. Ruiz-Ruiz, S.; Soler, N.; Sánchez-Navarro, J.; Fagoaga, C.; López, C.; Navarro, L.; Moreno, P.; Peña, L.; Flores, R. Citrus tristeza virus p23: Determinants for nucleolar localization and their influence on suppression of RNA silencing and pathogenesis. Mol. Plant-Microbe Interact. 2013, 26, 306-318. [CrossRef]

67. Gao, F.; Zhao, S.; Men, S.; Kang, Z.; Hong, J.; Wei, C.; Hong, W.; Li, Y. A non-structural protein encoded by Rice Dwarf Virus targets to the nucleus and chloroplast and inhibits local RNA silencing. Sci. China Life Sci. 2020, 63, 1703-1713. [CrossRef] [PubMed]

68. Haas, G.; Azevedo, J.; Moissiard, G.; Geldreich, A.; Himber, C.; Bureau, M.; Fukuhara, T.; Keller, M.; Voinnet, O. Nuclear import of CaMV P6 is required for infection and suppression of the RNA silencing factor DRB4. EMBO J. 2015, 34, 2591-2592. [CrossRef]

69. Martinez, F.; Daros, J.A. Tobacco etch virus protein P1 traffics to the nucleolus and associates with the host $60 \mathrm{~S}$ ribosomal subunits during infection. J. Virol. 2014, 88, 10725-10737. [CrossRef] 
70. Nakahara, K.S.; Masuta, C.; Yamada, S.; Shimura, H.; Kashihara, Y.; Wada, T.S.; Meguro, A.; Goto, K.; Tadamura, K.; Sueda, K.; et al. Tobacco calmodulin-like protein provides secondary defense by binding to and directing degradation of virus RNA silencing suppressors. Proc. Natl. Acad. Sci. USA 2012, 109, 10113-10118. [CrossRef] [PubMed]

71. Brodersen, P.; Sakvarelidze-Achard, L.; Bruun-Rasmussen, M.; Dunoyer, P.; Yamamoto, Y.Y.; Sieburth, L.; Voinnet, O. Widespread translational inhibition by plant miRNAs and siRNAs. Science 2008, 320, 1185-1190. [CrossRef]

72. Ghoshal, B.; Sanfacon, H. Temperature-dependent symptom recovery in Nicotiana benthamiana plants infected with tomato ringspot virus is associated with reduced translation of viral RNA2 and requires ARGONAUTE 1. Virology 2014, 456, 188-197. [CrossRef] [PubMed]

73. Pasin, F.; Simón-Mateo, C.; García, J.A. The hypervariable amino-terminus of P1 protease modulates potyviral replication and host defense responses. PLoS Path. 2014, 10, e1003985. [CrossRef] [PubMed]

74. Torres-Barcelo, C.; Darós, J.A.; Elena, S.F. Compensatory molecular evolution of HC-Pro, an RNA-silencing suppressor from a plant RNA virus. Mol. Biol. Evol. 2010, 27, 543-551. [CrossRef] [PubMed] 